\title{
Analisis faktor adopsi aplikasi mobile berdasarkan pengalaman, usia dan jenis kelamin menggunakan UTAUT2
}

\section{Raden Budiarto email: ${ }^{a}$ raden@jak-stik.ac.id

\begin{tabular}{l}
\hline I N F O A R T I K E L \\
\hline Sejarah artikel: \\
Menerima 22 Mei 2017 \\
Revisi 6 Juni 2018 \\
Diterima 6 Juni 2018 \\
Online 8 Juni 2018 \\
\hline Kata kunci: \\
aplikasi mobile \\
analisis pasar \\
adopsi teknologi \\
penerimaan teknologi \\
UTAUT
\end{tabular}

Sistem Informasi, STMIK Jakarta STI\&K, Jakarta, Indonesia

\section{Keywords: \\ mobile application \\ market analysis \\ UTAUT \\ technology acceptance \\ technology adoption}

\section{Style APA dalam mensitasi} artikel ini:

Budiarto, R. (2017). Analisis faktor adopsi aplikasi mobile berdasarkan pengalaman, usia dan jenis kelamin menggunakan UTAUT2. Register: Jurnal Ilmiah Teknologi Sistem Informasi, 3(2), 114-126.

\begin{abstract}
A B S T R A K
Tulisan ini menganalisis faktor adopsi mobile berdasarkan kriteria pengalaman, usia dan jenis kelamin. Penelitian ini merupakan eksplorasi dan pengembangan lanjutan dari model UTAUT2 (Unified Theory of Acceptance and Use of Technology). Beberapa variabel seperti kebiasaan dan kecemasan telah ditambahkan untuk menjelaskan penerimaan teknologi pada sisi konsumen. Di samping itu variabel moderator pengalaman, usia dan jenis kelamin telah dihipotesiskan pengaruhnya. Data yang digunakan penelitian ini diperoleh hasil pengolahan kuesioner dengan sampel convenient yang melibatkan partisipasi 384 responden. Data yang terkumpul selanjutnya diolah dengan Pemodelan Persamaan Struktur (PPS) atau Structural Equation Modelling (SEM) menggunakan alat bantu aplikasi IBM SPPS 21 dan Amos 22. Hasil dari penelitian ini telah menunjukkan hasil uji empiris yang telah mendukung model teoritis yang diajukan. Dibandingkan dengan hasil penelitian terdahulu, hasil penelitian ini menunjukkan peran dominan nilai harga dan motivasi hedonis sebagai penentu pada niat perilaku. Efek nilai harga berbanding terbalik dengan niat perilaku sedangkan motivasi hedonis berbanding lurus dengan niat perilaku. Implikasi temuan dari variabel moderati yakni pengalaman, usia dan jenis kelamin juga ditemukan memiliki efek terhadap jenis adopsi aplikasi yang digunakan.
\end{abstract}

\section{A B S T R A C T}

This paper analyzes mobile adoption factors based on age, gender and experience criteria. This study is an advanced development of UTAUT2 (Unified Theory of Acceptance and Use of Technology) model, that applied in the context of adoption mobile applications. There are some variables such as habits and anxiety have been added to explain the acceptance of technology on the consumer view. In addition, moderator variable age, gender and using experience have been hypothesized. The data used in this study obtained from the questionnaire using the method of convenient sampling with involved the participation of 384 respondents. The collected data is then analyzed by the Structural Equation Modelling (SEM) using IBM SPPS version 21 and Amos version 22 program tools. The results of this study show that the results supported the proposed theoretical model. Compared with the results of previous studies, the results of this study indicate the effect of price value and hedonic motivation as a determinant of behavioral intent. The effect of the value of the price is inversely proportional to the behavioral intention while the hedonic motivation is directly proportional to the behavioral intention. Implications of findings from moderate variables i.e. experience, age and gender were also found to influence the type of adoption of the applications used.

(c) 2017 Register: Jurnal IImiah Teknologi Sistem Informasi. Semua hak cipta dilindungi undang-undang.

\section{Pendahuluan}

Produk-produk dan jasa berbasis Teknologi Informasi (TI) kini merambah ke berbagai lapisan masyarakat. Perusahaan dan developer TI kini bersaing untuk mendapatkan tempat di hati konsumen. Akan tetapi dibalik segala kemajuan dan inovasi di bidang TI khususnya rekayasa perangkat lunak, 
tidak dapat terlepas dari berbagai masalah yang dihadapi. Perkembangan TI di bidang rekayasa perangkat lunak tidak serta-merta berpengaruh secara positif terhadap adopsi perangkat lunak itu sendiri pada level konsumen (Group, 2014). Slah satu faktor permasalahan non teknis implementasi dari sistem informasi adalah dari sisi penerimaan sistem informasi tersebut (Murtadho \& Wahid, 2016). Terkait dengan rendahnya tingkat adopsi perangkat lunak ini, beberapa peneliti terdahulu telah mengeksplorasi teori-teori sosial dan psikologi untuk menjelaskan faktor-faktor yang menyebabkan masalah ini di antaranya (Van Der Heijden, 2004). Sekalipun demikian teori-teori penerimaan teknologi yang ada saat ini masih terbatas penggunaannya dalam konteks organisasi atau perusahaan. Penelitian yang mencakup ke dalam konteks yang lebih individual seperti pada penerimaan konteks teknologi informasi pada sisi konsumen saat ini masih sangat terbatas (Venkatesh, Thong, \& Xu, 2012).

Teori adopsi TI ini juga telah menarik perhatian beberapa peneliti lokal. Kebanyakan dari mereka menggunakan teori yang telah ada seperti Technology Acceptance Model (TAM) dan Unified Theory of Acceptance and Use of Technology (UTAUT) sekedar untuk melakukan replikasi dan konfirmasi teori (Budiarto, 2013). Bidang yang diteliti antara lain pada bidang pendidikan Ramdhani (2009), Widiatmika dan Sensuse (2008), Sedana dan Wijaya (2010) dan sistem teknologi informasi yang menunjang kegiatan bisnis pada perusahaan tertentu (Handayani, 2007), (Gabby, 2011). Menariknya secara keseluruhan penelitian-penelitian tersebut telah mengonfirmasi teori yang ada, namun sangat disayangkan penelitian-penelitian tersebut menyingkirkan variabel yang seharusnya ada pada model empiris, terutama variabel moderator dan variabel mediasi.

Meskipun perkembangan TI yang kini telah merambah ke level individu, manfaat keberadaan produk TI kini bisa dirasakan setiap individu, akan tetapi pada sisi lain penelitian-penelitian adopsi teknologi cenderung stagnan pada level jenuh (Benbasat \& Barki, 2007). Kebanyakan peneliti cenderung sekedar untuk melakukan replikasi dan generalisasi teori yang ada ketimbang memperluasnya seperti (Bagozzi, 2007). Pada sisi lain perangkat lunak sendiri memiliki karakteristik tersendiri, yakni tidak berwujud fisik (Pressman \& Maxim, 2014). Sebuah perangkat lunak dapat saja berkualitas buruk sekalipun memiliki desain atau tampilan yang menarik. Fenomena ini mengundang minat penulis untuk mengeksplorasi lebih jauh, apa saja faktor yang mempengaruhi seseorang untuk dapat menerima teknologi perangkat lunak. Beberapa peneliti telah menyarankan untuk mengeksplorasi pada tingkat adopsi teknologi lebih lanjut dengan menelusuri karakteristik individu seperti usia dan jenis kelamin (Venkatesh, Davis, \& Morris, 2007). Terdapat juga dari peneliti lainnya menambahkan teori-teori baru dari sudut pandang ekonomi ketimbang teori-teori dari psikologi dan sosial yang sudah populer digunakan (Brown, Venkatesh, \& Goyal, 2014).

Masalah yang akan diteliti akan dibatasi, yakni hanya terkait dengan penerimaan teknologi perangkat lunak dalam bentuk aplikasi mobile pada konsumen. Konsumen di sini ditujukan bagi para pengguna aplikasi mobile. Untuk batasan aplikasi mobile di sini mencakup segala macam perangkat lunak yang dapat diinstal pada sistem operasi perangkat mobile, baik berupa telepon genggam, smartphone maupun tablet. Sejalan dengan permasalahan yang akan diteliti, tujuan pada penelitian ini adalah untuk memperoleh bukti empiris pengaruh dari variabel motivasi hedonis, nilai harga, kebiasaan, kecemasan, pengalaman, usia dan jenis kelamin terhadap niat perilaku penggunaan aplikasi mobile dalam perspektif konsumen

Hasil temuan penelitian ini diharap mampu untuk memberikan kontribusi manajerial bagi para manajer untuk lebih mengenal target pemasaran teknologi informasi ke masyarakat umum, khususnya aplikasi mobile. Hasil temuan dari penelitian ini diharapkan lebih memberikan sasaran target pemasaran yang lebih tepat dan terarah berdasarkan kategori tingkat pendidikan, jenis kelamin serta usia. Pada sisi lain bagi pengembang perangkat lunak, maka hasil penelitian nantinya bisa dijadikan sebagai acuan bagi para pengembang aplikasi khususnya yang berbasis mobile untuk menentukan arah pengembangan aplikasi yang lebih berorientasi kepada pengguna.

\section{Tinjauan Pustaka \& Pengembangan Hipotesis}


Berbagai penelitian seputar adopsi teknologi informasi telah dipelajari selama lebih dari dua dekade. Penelitian tentang adopsi teknologi mulai marak sejak TAM (Davis, 1989), yang terintegrasi perspektif teoritis beragam dan dibangun di atas basis ilmu sosial psikologi. Sebagian besar penelitian tentang adopsi teknologi sebelum TAM hanya memeriksa kepuasan pengguna dan sikap.

Model TAM termasuk valid, dapat diandalkan serta telah terbukti secara empiris lebih unggul ketimbang teori yang lebih umum seperti Theory of Reasoned Action (TRA) (Ajzen \& Fishbein, 1980). Model orisinal TAM sudah sering dikutip dalam penelitian, baik bidang sistem Informasi dan di bidang lain dengan lebih dari 10.000 kutipan (Lee, Kozar, \& Larsen, 2003), sehingga memiliki dampak yang signifikan.

Beberapa penelitian juga melaporkan berbagai perbandingan teori adopsi teknologi yang ada, Mathieson (1991) menyimpulkan bahwa TAM dapat menjelaskan variabel sikap terhadap teknologi (attitude toward technology) lebih baik ketimbang Theory of Planned Behavior (TPB). Kemudian (Hubona \& Cheney, 2004) menyatakan model TAM lebih sederhana dan lebih baik untuk menjelaskan model penerimaan teknologi.

Penelitian seputar adopsi teknologi informasi telah menunjukkan progres yang positif. Penelitian adopsi teknologi informasi telah banyak direplikasi, digeneralisasi dan dikembangkan lebih lanjut. Berbagai macam penelitian seputar penerimaan teknologi informasi dalam kurun waktu 5 tahun terakhir disajikan pada Tabel 1.

Tabel 1. Hasil penelitian-penelitian terkait

\begin{tabular}{ll}
\hline \multicolumn{1}{c}{ Peneliti } & \multicolumn{1}{c}{ Hasil penelitian } \\
\hline Venkatesh, Thong, \& & $\begin{array}{l}\text { Peneliti memperluas konteks model penerimaan teknologi pada sudut pandang } \\
\text { ku ( 2012) }\end{array}$ \\
Vensumen. Peneliti menambahkan berbagai variabel baru untuk memprediksi sikap \\
seorang konsumen dalam mengadopsi produk teknologi informasi. \\
Peneliti mencoba mengatasi kelemahan yang belum terjawab pada model penerimaan \\
teknologi informasi sebelumnya, yakni bagaimana intervensi seorang manajer dapat \\
meningkatkan penerimaan teknologi pada karyawan. \\
Benbasat \& Barki & $\begin{array}{l}\text { Peneliti menyatakan model TAM sekalipun telah memberikan dampak yang } \\
\text { signifikan dalam teori penerimaan teknologi, namun pada sisi lain TAM sudah terlalu } \\
\text { banyak direplikasi sehingga telah mengaburkan tujuan sebenarnya dari model TAM. }\end{array}$ \\
Murugesh-Warren, et & $\begin{array}{l}\text { Peneliti menggunakan metode UTAUT 2 untuk memahami faktor-faktor yang } \\
\text { mempengaruhi adopsi dan penerimaan teknologi mobile dalam konteks layanan }\end{array}$ \\
& $\begin{array}{l}\text { kesehatan. Menganalisis faktor bagaimana dan mengapa orang menerima atau } \\
\text { menolak teknologi dengan variabel moderati usia. }\end{array}$ \\
\hline
\end{tabular}

Berdasarkan penelitian-penelitian sebelumnya, penelitian ini menyusulkan sebuah kerangka pemikiran yang akan digunakan untuk membangun hipotesis. Model kerangka pemikiran pada penelitian ini menggunakan gabungan dari beberapa model pada penelitian sebelumnya. Berdasarkan penelitian-penelitian sebelumnya, serta model pemikiran yang telah diajukan, penelitian ini mengembangkan 6 hipotesis untuk kemudian akan diuji untuk dibuktikan secara empiris kebenaran dari hipotesis tersebut. Fokus pengembangan hipotesis pada penelitian hanya akan dilakukan pada konteks konsumen dengan variabel moderati usia, jenis kelamin serta pengalaman.

Bagi konsumen dengan usia lebih tua, maka cenderung menemui kesulitan lebih ketika memproses informasi yang baru atau kompleks. Hal ini akan mempengaruhi pembelajaran mereka terhadap teknologi baru (Venkatesh, Morris, \& Davis, 2003), (Morris, Venkatesh, \& Ackerman, 2005). Kesulitan ini mungkin disebabkan penurunan kemampuan kognitif dan memori yang berhubungan dengan proses penuaan. Dengan demikian jika dibandingkan dengan konsumen yang lebih muda, mereka yang lebih tua cenderung lebih mengandalkan ketersediaan dukungan penggunaan yang memadai.

Selain itu, pria cenderung bersedia untuk meluangkan lebih banyak waktu dan usaha untuk mengatasi kendala yang ada dan berusaha untuk mengejar tujuan mereka, sedangkan wanita cenderung lebih mempertimbangkan besarnya usaha serta proses untuk mencapai tujuan mereka 
(Venkatesh \& Morris, 2000), (Henning \& Jardim, 1977). Hasil penelitian sebelumnya juga menunjukkan bahwa pengguna yang kurang pengalaman akan lebih bergantung pada memfasilitasi kondisi (Notani, 1998). Dengan demikian dapat dinyatakan hipotesis pertama sebagai berikut:

H1: Pengalaman, usia dan jenis kelamin akan memoderati efek kondisi-kondisi yang memfasilitasi pada niat perilaku, efeknya akan lebih kuat pada wanita yang lebih tua dan kurang berpengalaman.

Selanjutnya, usia dan jenis kelamin telah ditemukan terkait dengan daya inovasi konsumen (Lee, Cho, Xu, \& Fairhurst, 2010). Pada fase awal menggunakan teknologi baru, pria usia lebih muda cenderung menunjukkan kegemaran untuk mengeksplorasi hal-hal yang baru (Chau \& Hui, 1998). Kecenderungan yang lebih besar ini pada gilirannya akan meningkatkan motivasi hedonis dalam keputusan penggunaan teknologi. Sebagai akibatnya efek moderati pengalaman akan berbeda di berbagai usia dan jenis kelamin. Dengan demikian maka dapat dinyatakan hipotesis kedua sebagai berikut:

H2: Pengalaman, usia dan jenis kelamin akan memoderati pengaruh motivasi hedonis pada niat perilaku, sehingga efeknya akan lebih kuat pada pria yang lebih muda dengan pengalaman yang lebih minim.

Pada penelitian (Sam, Othman, \& Nordin, 2005) juga diungkap bahwa jenis kelamin dapat memoderati efek kecemasan. Wanita cenderung lebih sensitif dengan perasaannya dan peran sosial lebih dekat dengan efek cermin sosial lingkungan sekitarnya. Kedua sebab ini pada akhirnya menjadikan efek kecemasan lebih besar wanita ketimbang pria. Selanjutnya pada usia yang lebih muda seseorang cenderung berpikiran bebas tanpa memikirkan risiko panjang, sebaliknya usia yang tua seseorang cenderung lebih berhati-hati terhadap risiko. Hal ini dapat berbanding terbalik dengan tingkat pengalaman, semakin tinggi pengalaman maka kekhawatiran terhadap risiko semakin mengecil, berbeda dengan mereka yang belum begitu berpengalaman, cenderung memiliki kekhawatiran yang lebih besar. Oleh karena itu dapat dijabarkan hipotesis ketiga sebagai berikut:

$H_{3}:$ Pengalaman, usia dan jenis kelamin akan memoderati pengaruh kecemasan pada niat perilaku, sehingga efeknya akan lebih kuat di kalangan wanita yang lebih tua dengan pengalaman lebih sedikit.

Masalah apakah efek dari kebiasaan berpengaruh langsung pada perilaku atau melalui niat perilaku telah banyak dibahas dalam penelitian sebelumnya (Ajzen, 2002) \& (Kim, Malhotra, \& Narasimhan, 2005). Sebagai contoh setelah memiliki kebiasaan membaca email pada perangkat mobile saat bepergian dalam kendaraan umum, konsumen mungkin telah mengembangkan pandangan positif terhadap teknologi mobile misalnya, memeriksa email menggunakan mobile internet selama bepergian berguna dan hal ini juga terkait niat perilaku. Konsumen dengan pengalaman lebih banyak pada penggunaan teknologi tertentu akan mengembangkan daya tarik kognitif yang menciptakan halangan bagi perubahan perilaku (Murray \& Häubl, 2007). Maka pola kebiasaan diduga memiliki efek dominan pada niat dan dapat diterapkan untuk konsumen yang lebih berpengalaman. Dengan demikian maka secara seksama akan diuji hipotesis keempat dan kelima yaitu:

H4: Pengalaman, usia dan jenis kelamin akan memoderati pengaruh kebiasaan pada niat perilaku, sehingga efeknya akan lebih dirasakan bagi pria yang lebih tua dengan tingkat pengalaman dengan teknologi yang lebih banyak

$H_{5:}$ Pengalaman, usia dan jenis kelamin akan memoderati pengaruh kebiasaan pada penggunaan teknologi, sehingga efeknya akan lebih kuat untuk pria yang lebih tua dengan tingkat pengalaman dengan teknologi yang lebih banyak.

Wanita cenderung lebih memperhatikan harga produk dan jasa, dan lebih sadar biaya daripada pria. Selanjutnya, wanita biasanya lebih banyak terlibat dalam pembelian dengan demikian lebih bertanggung jawab dan berhati-hati dengan uang daripada pria (Slama \& Tashchian, 1985). Mengingat kecenderungan pria untuk bermain dengan teknologi, nilai harga yang diberikan oleh pria untuk teknologi kemungkinan akan lebih tinggi dari nilai yang diberikan oleh wanita untuk teknologi yang sama. Peran sosial ini diperkuat dengan usia, karena wanita yang lebih tua lebih mungkin untuk 
Budiarto, R./ Register 3 (2) 114-126 terlibat dalam kegiatan seperti mengurus keluarga mereka (Deaux \& Lewis, 1984). Dengan demikian,
wanita yang lebih tua akan lebih sensitif terhadap harga karena peran sosial mereka sebagai penjaga gerbang pengeluaran keluarga. Ini berarti bahwa nilai harga akan lebih penting untuk wanita yang lebih tua. Dengan demikian dapat dikembangkan hipotesis keenam yakni:

H6: Usia dan jenis kelamin akan memoderati pengaruh nilai harga pada niat perilaku, sehingga efeknya akan lebih kuat di kalangan wanita, terutama wanita yang lebih tua.

\section{Metode Penelitian}

Penelitian ini melibatkan beberapa langkah yang tertuang dalam satu kerangka penelitian. Alur penelitian ini dapat dilihat pada Error! Reference source not found.. Alur penelitian ini menunjukkan langkah demi langkah yang dilalui saat proses penelitian.

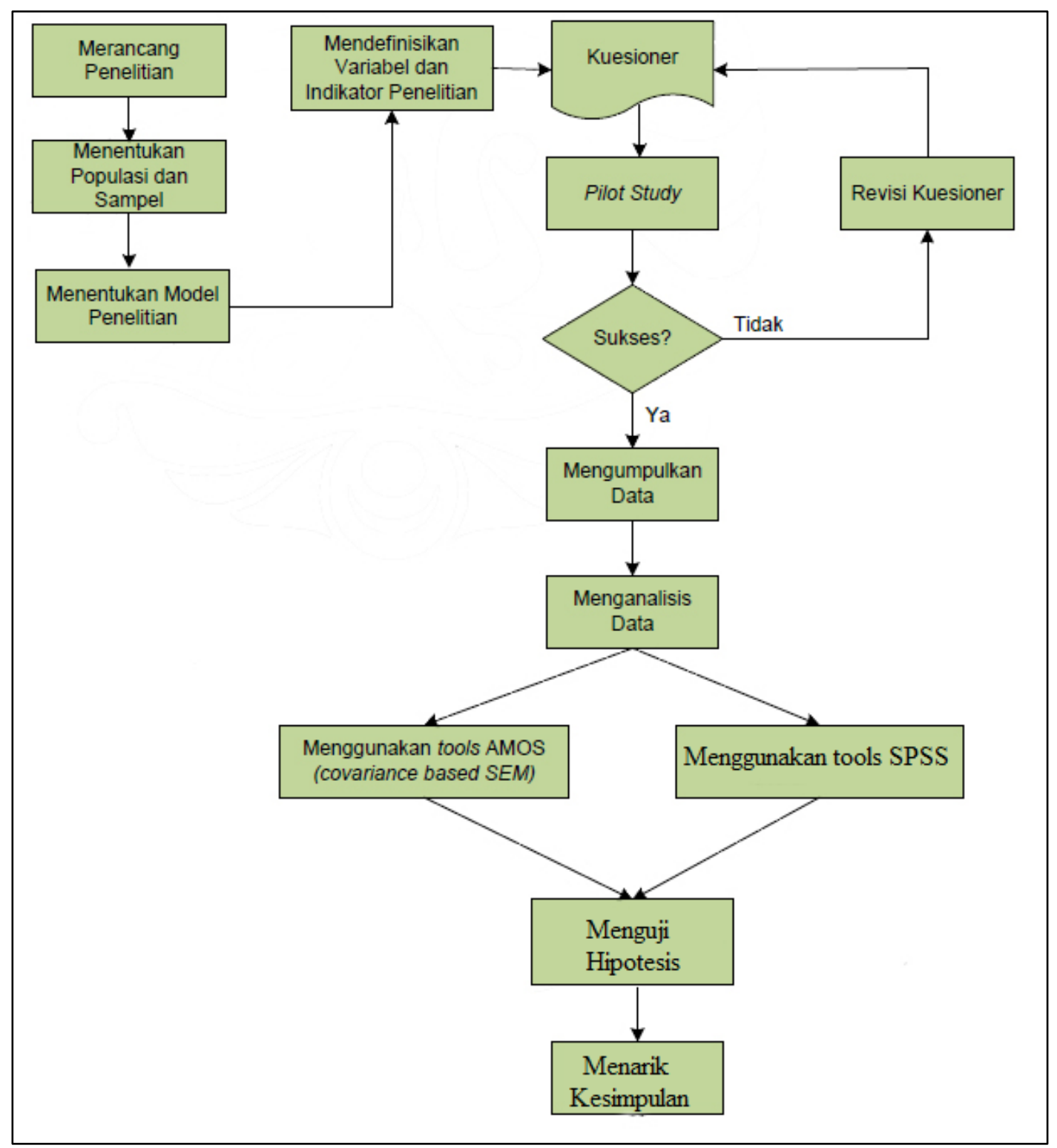

Gambar 1 Alur Penelitian

\subsection{Populasi dan sampel}

Populasi dari penelitian ini adalah penduduk warga negara Indonesia yang memiliki perangkat mobile (handphone, smartphone atau tablet). Dalam memilih sampel, penelitian ini menggunakan teknik gabungan antara convenient sampling dan random sampling, peneliti tidak mempunyai pertimbangan lain untuk menggunakan convenient sampling kecuali berdasarkan kemudahan saja. Peneliti juga 
menggunakan teknik random sampling yang dilakukan secara kuesioner online melalui situs website di internet.

\subsection{Variabel penelitian}

Penelitian ini menggunakan 13 variabel penelitian yang terdiri dari 8 variabel eksogen (ekspektasi kegunaan, ekspektasi kemudahan, pengaruh sosial, kondisi-kondisi yang memfasilitasi, nilai harga, motivasi hedonis dan kebiasaan), 2 variabel endogen (niat perilaku dan perilaku penggunaan), serta 3 variabel moderator (pengalaman, usia dan jenis kelamin). Penjelasan dari masing-masing variabel dapat dilihat pada Error! Reference source not found.. Kemudian dari variabel-variabel tersebut masing-masing telah memiliki indikator-indikator yang menjadi instrumen pengukuran. Ke semua indikator tersebut sudah divalidasi kecocokannya dengan konstruk yang diwakilinya. Indikator tersebut dijabarkan pada Error! Reference source not found. dengan tetap mempertahankan bahasa asli pada penelitian terkait agar tidak mengubah validitas dari instrumen pengukuran tersebut.

Tabel 2. Definisi variabel penelitian

\begin{tabular}{|c|c|}
\hline Nama Variabel & Definisi \\
\hline Ekspektasi kegunaan [EG] & $\begin{array}{l}\text { Tingkat di mana seorang individu percaya bahwa menggunakan suatu sistem } \\
\text { atau aplikasi akan membantu untuk mendapat keuntungan dalam kinerjanya. }\end{array}$ \\
\hline Ekspektasi kemudahan [EM] & Tingkat kemudahan dalam pengguna sebuah sistem atau aplikasi. \\
\hline Pengaruh sosial [PS] & $\begin{array}{l}\text { Sejauh mana seorang individu menganggap bahwa orang lain akan } \\
\text { mempengaruhi dirinya untuk menggunakan sistem/aplikasi. }\end{array}$ \\
\hline $\begin{array}{l}\text { Kondisi-kondisi yang } \\
\text { memfasilitasi [KF] }\end{array}$ & $\begin{array}{l}\text { Tingkat di mana seorang individu percaya terdapat adanya infrastruktur atau } \\
\text { sumber daya dan bantuan teknis yang akan mendukung penggunaan } \\
\text { sistem/aplikasi }\end{array}$ \\
\hline Nilai harga $[\mathrm{NH}]$ & $\begin{array}{l}\text { Seberapa biaya atau harga yang harus dikeluarkan untuk mendapatkan nilai } \\
\text { manfaat suatu sistem/aplikasi }\end{array}$ \\
\hline Motivasi hedonis [MD] & $\begin{array}{l}\text { Sejauh mana tingkat perasaan senang atau kenikmatan ketika seseorang } \\
\text { menggunakan sistem atau aplikasi }\end{array}$ \\
\hline Kebiasaan $[\mathrm{KB}]$ & $\begin{array}{l}\text { Sejauh mana seseorang cenderung untuk melakukan perilaku yang rutin dan } \\
\text { berkesinambungan terhadap suatu sistem/aplikasi }\end{array}$ \\
\hline Kecemasan [KC] & Sejauh mana tingkat perasaan cemas saat menggunakan aplikasi/sistem \\
\hline Niat perilaku [NP] & $\begin{array}{l}\text { Tingkat keinginan atau niat pemakai menggunakan sistem atau aplikasi secara } \\
\text { terus menerus }\end{array}$ \\
\hline Perilaku penggunaan $[\mathrm{PP}]$ & Tingkat seberapa sering seseorang menggunakan suatu sistem atau aplikasi \\
\hline Usia & Usia responden pada saat pengambilan data dalam satuan tahun \\
\hline Jenis kelamin & Jenis kelamin responden (pria atau wanita) \\
\hline Pengalaman & $\begin{array}{l}\text { Pengalaman responden dalam menggunakan suatu sistem atau aplikasi dalam } \\
\text { satuan tahun }\end{array}$ \\
\hline
\end{tabular}

\subsection{Teknik pengumpulan dan analisis data}

Data yang diambil selama penelitian ini adalah data primer langsung dari sejumlah responden dalam bentuk kuesioner. Metode sampling yang digunakan adalah gabungan dari random sampling. Untuk metode random sampling digunakan kuesioner online yang dapat diakses pada http://www.jakstik.ac.id/raden/kuis/kuisioner-aplikasi-mobile/. Penyebaran kuesioner dilakukan pada bulan Agustus dan September 2016. Untuk meningkatkan tingkat respons pada kuesioner online, ada yang hal dilakukan oleh peneliti antara lain:

1) Memberikan hadiah $e$-book

2) Menyebarkan link kuesioner pada sosial media \& milis email

3) Untuk mengurangi missing data value, kuesioner online tidak dapat dikirim kecuali jika semua pertanyaan sudah terisi

Data yang dikumpulkan kemudian dianalisis menggunakan program Microsoft Excel 2013, IBM SPSS versi 21 dan IBM Amos versi 21. Setelah melakukan penelusuran ada kuesioner untuk menentukan apakah ada yang diisi valid atau tidak, maka tahap selanjutnya ada beberapa tahap analisis data yang dilakukan, pertama analisis deskriptif untuk menjelaskan nilai rata-rata dan standar 
deviasi dari hasil kuesioner pada masing-masing konstruk. Pada tahap kedua dilakukan uji normalitas untuk memastikan data yang telah terkumpul sudah sesuai dengan kurva distribusi normal, karena analisis Structural Equation Modelling (SEM) mengharuskan data terdistribusi normal (El-Qadri \& Wijaya, 2013), pada tahap ini data-data outlier akan dihapus.

Tahap selanjutnya dilakukan pengujian mutu data dengan uji validitas dan reliabilitas data. Uji validitas data untuk mengukur seberapa besar pertanyaan-pertanyaan kuesioner penelitian benarbenar mengukur konsep/variabel yang diukur (Mustakini, 2008) sedangkan Uji reliabilitas untuk mengukur tingkat konsistensi data. Peneliti mengikuti saran dari (Widhiarso, 2012) untuk menggunakan teknik Average Varian Extracted (AVE) untuk mengukur validitas, serta menggunakan reliabilitas konstruk ketimbang koefisien Cronbach's alpha untuk reliabilitas. Pengujian validitas konstruk meliputi validitas konvergen dan validitas diskriminan. Sampel data dan instrumen penelitian dikatakan berkualitas jika dapat memenuhi aturan batas minimal (rule of thumb), untuk mengetahui batasan rule of thumb lihat pada Tabel 3.

Tabel 3. Rule of thumb validitas \& reliabilitas (Hair, Black, Babin, \& Anderson, 2010)

\begin{tabular}{lll}
\hline \multicolumn{1}{c}{ Kriteria } & \multicolumn{1}{c}{ Parameter } & \multicolumn{1}{c}{ Rule of Thumb } \\
\hline Validitas konvergen & $\begin{array}{l}\text { Average Varian Extracted } \\
\text { (AVE) }\end{array}$ & $>0,5$ \\
Validitas konvergen & Muatan faktor & $>0,5$ \\
Validitas & Akar kuadrat AVE & Akar kuadrat AVE $>$ dari korelasi antar konstruk \\
$\begin{array}{l}\text { Diskriminan } \\
\text { Validitas }\end{array}$ & AVE & lainnya \\
$\begin{array}{l}\text { Diskriminan } \\
\text { Reliabilitas }\end{array}$ & Reliabilitas Konstruk & AVE $>$ ASV \\
\hline
\end{tabular}

Pada tahap analisis data berikutnya dilakukan teknik pengukuran analisis faktor konfirmatori. Karena model yang diuji menggunakan satu variabel mediasi yakni niat perilaku, maka setelah analisis faktor konfirmatori dilakukan kembali analisis faktor konfirmatori tahap kedua untuk mengetahui besaran pengaruh masing-masing variabel eksogen terhadap variabel endogen. Metode estimasi yang digunakan adalah maksimum likelihood (Garson, 2015).

Setelah tahap analisis faktor konfirmatori, maka tahap selanjutnya dilakukan uji fit model SEM. Tahap ini merupakan tahap yang sangat penting untuk mengukur seberapa kecocokan model yang diujikan dengan data sampel di lapangan. Beberapa aturan Goodness of Fit (GoF) digunakan untuk mengukur kecocokan model. Peneliti mengikuti rekomendasi dari Garson (2015) untuk menggunakan minimal GoF dari Root Mean Square Error of Approximation (RSMEA), Chi Square, base fit model (CFI), parsimony fit model (PNFI) dan information theory model (AIC). Terakhir untuk pengujian hipotesis dari efek moderati pengalaman, usia dan jenis kelamin peneliti menggunakan teknik Fisher's Z-test (Budiarto, 2013). Z-test merupakan teknik perbandingan rata-rata pada yang di sini berguna untuk membandingkan beberapa grup berdasarkan variabel moderati masing-masing. Perbedaan tingkat signifikansi akan digunakan menjawab hipotesis-hipotesis yang telah dibangun.

\section{Hasil dan Pembahasan}

Untuk pengujian hipotesis yang pertama akan diuji peran niat perilaku dalam mediasi pengaruh motivasi hedonis, nilai harga, kecemasan dan kebiasaan terhadap perilaku penggunaan. Teknik pengujian menggunakan rumus z-statistic seperti pada Rumus 1,

$z=\frac{\mathrm{a} \times \mathrm{b} \mathrm{x} \ldots}{\sqrt{\mathrm{b}^{2} x} s a^{2}+\sqrt{a^{2} x s b^{2}}+\sqrt{\ldots}}$

di mana: $a, b$ adalah nilai koefisien jalur dan $s a$, sb adalah standar error untuk $a$ dan $b$. Berdasarkan pada hasil efek langsung dan efek tidak langsung pada Tabel 4, maka didapati nilai $z$ adalah 1,43 nilai masih berada dalam rentang kurva distribusi normal $(-1,96-1,96)$. Selain itu didapati nilai $R^{2}=0,617$ hal ini 
berarti $61,7 \%$ koefisien pada niat perilaku dapat dijelaskan oleh variabel independen. Maka dapat disimpulkan bahwa niat perilaku merupakan variabel mediator antara motivasi hedonis, nilai harga, kecemasan dan kebiasaan terhadap perilaku penggunaan.

Tabel 4. Hasil uji efek mediasi niat perilaku

\begin{tabular}{lcc}
\multicolumn{1}{c}{ Konstruk } & Efek Langsung & Efek tidak langsung \\
\hline Motivasi Hedonis & 0,42 & 0,62 \\
Nilai Harga & 0,44 & 0,66 \\
Kecemasan & 0,27 & 0,48 \\
Kebiasaan & 0,26 & 0,44 \\
R-Square: 0,617 & & \\
\hline
\end{tabular}

Berdasarkan hasil tersebut dengan demikian baik $\mathrm{H}_{1}$ terima. Hal ini sejalan dengan berbagai penelitian sebelumnya (Kim, Malhotra, \& Narasimhan, 2005), (Limayem, Hirt, \& Cheung, 2007), (Ajzen \& Fishbein, 2005).

\subsection{Hasil pengaruh efek moderati jenis kelamin}

Tahap pengujian hipotesis berikut adalah menguji perbedaan efek moderati antara jenis kelamin pria dan wanita. Pengujian ini akan menggunakan uji nilai $z$ untuk membandingkan rata-rata muatan faktor antar kelompok responden pria dan wanita. Hasil nilai $z$ dapat dilihat pada Tabel 5.

Tabel 5. Hasil uji efek moderati jenis kelamin

\begin{tabular}{|c|c|c|c|c|c|c|c|}
\hline & & & Pria & & Wanita & & \\
\hline & & & Estimasi & $\mathbf{P}$ & Estimasi & $\mathbf{P}$ & Nilai z \\
\hline $\mathrm{KB}$ & $<---$ & PP & 1,531 & 0 & 1,030 & 0 & $-1,154^{*}$ \\
\hline $\mathrm{KB}$ & $<---$ & NP & 2,111 & 0,011 & 1,432 & 0,003 & $-1,087^{*}$ \\
\hline KF & $<---$ & PP & 1,051 & 0 & 1,251 & 0 & 0,089 \\
\hline KF & $<---$ & NP & 0,909 & 0 & 2,432 & 0 & $1,864^{*}$ \\
\hline EM & $<---$ & NP & 0,966 & 0 & 1,266 & 0 & $1,098^{*}$ \\
\hline PS & $<---$ & NP & 0,995 & 0 & 0,895 & 0,05 & 0,098 \\
\hline EG & $<---$ & NP & 2,831 & 0 & 0,933 & 0 & $1,462^{*}$ \\
\hline MD & $<---$ & NP & 2,944 & 0,098 & 0,984 & 0 & $-2,877^{*}$ \\
\hline $\mathrm{KC}$ & $<---$ & NP & 0,864 & 0,004 & 1,264 & 0 & $1,041^{*}$ \\
\hline $\mathrm{NH}$ & $<---$ & NP & 0,852 & 0,003 & 1,742 & 0,007 & $1,345^{*}$ \\
\hline
\end{tabular}

Berdasarkan Tabel 5 dapat dinyatakan bahwa nilai $z$ dengan tanda * menunjukkan terdapat perbedaan signifikan antara pria dengan wanita. Nilai estimasi memberikan pengukuran muatan faktor yang dapat dijelaskan variabel eksogen. Hubungan kebiasaan $[K B]$ dengan perilaku penggunaan $[P P]$ (keterangan variabel merujuk pada Tabel 2) mendapati nilai $z$ yang signifikan, berarti jenis kelamin memberikan efek moderati pada hubungan ini. Nilai estimasi yang ada menunjukkan angka 1,531 pada pria dan 1,030 pada wanita, hal berarti efek moderati akan cenderung lebih signifikan pada pria ketimbang wanita. 
Secara keseluruhan hasil moderati jenis kelamin ditunjukkan pada hubungan kebiasaan dengan niat perilaku dan perilaku penggunaan, ekspektasi kegunaan dengan niat perilaku, ekspektasi kemudahan dengan niat perilaku, juga pada motivasi hedonis, kondisi-kondisi yang memfasilitasi, kecemasan serta nilai harga. Nilai $z$ positif menunjukkan efek yang lebih kuat pada wanita, sedangkan nilai negatif menunjukkan hubungan yang lebih kuat pada pria.

Hasil yang ada secara keseluruhan hipotesis terkait efek moderati jenis kelamin diterima. Hal ini sejalan dengan beberapa temuan dan teori-teori sebelumnya serta penjabaran logika yang telah diuraikan saat membangun hipotesis.

\subsection{Hasil pengaruh efek moderati pengalaman}

Tahap selanjutnya akan ditelusuri pengaruh efek moderati dari pengalaman. Karena pengalaman merupakan data kontinu, maka untuk menguji pengaruh moderati harus diubah terlebih dahulu menjadi data kategorial, dengan cara terlebih dahulu menentukan nilai median. Nilai median yang diperoleh adalah 3 tahun dengan demikian usia di bawah 3 dikategorikan berpengalaman, sedangkan sisanya dikategorikan kurang berpengalaman.

Setelah dikategorikan maka akan dilakukan uji nilai $z$ untuk membandingkan rata-rata muatan faktor antar kelompok responden yang berpengalaman dengan yang kurang berpengalaman. Hasil nilai $z$ dapat dilihat pada Tabel 6 .

Tabel 6. Hasil uji efek moderati pengalaman

\begin{tabular}{|c|c|c|c|c|c|c|c|}
\hline & & & \multicolumn{2}{|c|}{ Berpengalaman } & \multicolumn{3}{|c|}{ Kurang Berpengalaman } \\
\hline & & & Estimasi & $\mathbf{P}$ & Estimasi & $\mathbf{P}$ & Nilai z \\
\hline KB & $<--$ & $\mathrm{PP}$ & 2,984 & 0 & 1,543 & 0 & $-1,438^{*}$ \\
\hline KB & $<--$ & NP & 2,438 & 0,001 & 1,654 & 0,007 & $-1,297^{*}$ \\
\hline $\mathrm{KF}$ & $<--$ & PP & 1,313 & 0 & 1,421 & 0 & 0,124 \\
\hline KF & $<---$ & $\mathrm{NP}$ & 0,911 & 0 & 2,476 & 0 & $1,752^{*}$ \\
\hline EM & $<---$ & NP & 0,966 & 0,002 & 1,266 & 0,009 & $1,098^{*}$ \\
\hline PS & $<---$ & NP & 0,532 & 0 & 1,546 & 0,005 & 0,436 \\
\hline EG & $<--$ & $\mathrm{NP}$ & 2,423 & 0 & 0,454 & 0 & $-1,786^{*}$ \\
\hline MD & $<--$ & NP & 2,944 & 0,398 & 1,584 & 0.001 & $-2,942^{*}$ \\
\hline KC & $<--$ & NP & 0,889 & 0 & 1,464 & 0 & $1,211^{*}$ \\
\hline $\mathrm{NH}$ & $<--$ & NP & 0,235 & 0,003 & 0,634 & 0,007 & 0,675 \\
\hline
\end{tabular}

Hasil yang ditunjukkan Tabel 6 menyatakan ada hubungan yang signifikan dari efek moderati pengalaman pada kebiasaan terhadap niat perilaku dan perilaku penggunaan, ekspektasi kegunaan dengan niat perilaku, ekspektasi kemudahan dengan niat perilaku, juga pada motivasi hedonis, kondisi-kondisi yang memfasilitasi, kecemasan. Nilai $z$ positif menunjukkan efek yang lebih kuat pada responden kurang berpengalaman sedangkan nilai negatif akan menunjukkan hubungan yang lebih kuat pada responden yang berpengalaman.

Hasil yang ada menunjukkan secara keseluruhan hipotesis terkait efek moderati pengalaman diterima. Hal ini sejalan dengan beberapa penelitian sebelumnya serta penjabaran logika yang telah diuraikan saat membangun hipotesis.

\subsection{Hasil pengaruh efek moderati usia}


Tahap pengujian hipotesis yang terakhir akan ditelusuri pengaruh efek moderati dari usia. Karena usia merupakan data kontinu, maka untuk menguji pengaruh moderati harus diubah menjadi data kategorial dengan terlebih dahulu dengan cara menentukan nilai median. Nilai median yang diperoleh adalah 22 tahun, dengan demikian usia di bawah 22 di kategorikan usia muda, sedangkan sisanya dikategorikan usia tua.

Seperti pada pengalaman, setelah usia dikategorikan, maka akan dilakukan uji nilai $z$ untuk membandingkan rata-rata muatan faktor antar kelompok responden yang muda dengan yang tua. Hasil nilai z dapat dilihat pada Tabel 7.

Tabel 7. Hasil uji efek moderati pengalaman

\begin{tabular}{|c|c|c|c|c|c|c|c|}
\hline & & & \multicolumn{2}{|l|}{ Tua } & \multicolumn{3}{|l|}{ Muda } \\
\hline & & & Estimasi & $\mathbf{P}$ & Estimasi & $\mathbf{P}$ & Nilai $z$ \\
\hline KB & $<---$ & PP & 0,876 & 0 & 0,344 & 0 & $-0,231$ \\
\hline KB & $<---$ & NP & 0,967 & 0 & 0,431 & 0 & $-0,322$ \\
\hline KF & $<---$ & PP & 1,051 & 0 & 1,352 & 0 & $-0,745$ \\
\hline KF & $<---$ & NP & 1,909 & 0 & 0,931 & 0 & $1,039^{*}$ \\
\hline EM & $<---$ & NP & 1,283 & 0 & 0,366 & 0 & $1,635^{*}$ \\
\hline PS & $<---$ & NP & 0,895 & 0 & 1,536 & 0 & $-0,938$ \\
\hline EG & $<---$ & NP & 0,453 & 0 & 1,831 & 0 & $2,122^{*}$ \\
\hline MD & $<---$ & NP & 0,984 & 0 & 2,138 & 0 & $1,363^{*}$ \\
\hline $\mathrm{KC}$ & $<---$ & NP & 0,864 & 0 & 0,912 & 0 & 0,212 \\
\hline $\mathrm{NH}$ & $<---$ & NP & 2,837 & 0 & 0,964 & 0 & $-2,153^{*}$ \\
\hline
\end{tabular}

Hasil yang ditunjukkan Tabel 7 menyatakan ada hubungan yang signifikan dari efek moderati usia pada motivasi hedonis terhadap niat perilaku, ekspektasi kegunaan dengan niat perilaku, ekspektasi kemudahan dengan niat perilaku, juga pada hubungan nilai harga dengan niat perilaku. Nilai $z$ positif menunjukkan efek yang lebih kuat pada responden muda sebaliknya nilai negatif akan menunjukkan hubungan yang lebih kuat pada responden yang tua.

Hasil yang ada mendukung hipotesis efek moderati usia pada kebiasaan terhadap niat perilaku dan perilaku penggunaan, nilai harga terhadap niat perilaku serta motivasi hedonis dan kondisikondisi yang memfasilitasi terhadap niat perilaku. Pada pencapaian logika dan teori-teori yang dijabarkan pada saat membangun hipotesis telah dikonfirmasi. Dengan demikian $H_{1}, H_{2}, H_{3}$ dan $H_{4}$ telah diterima sepenuhnya.

Sementara itu $H_{5}$ dan $H_{6}$ tidak didukung sepenuhnya, karena hasil pengujian tidak menunjukkan efek moderator usia yang signifikan. Dengan kata lain, usia tidak memoderati hubungan kebiasaan dengan niat perilaku, serta hubungan kebiasaan dengan perilaku penggunaan. Hal ini agaknya disebabkan karena penyebaran usia responden yang tidak merata. Nilai kurtosis usia cenderung tinggi disebabkan penyebaran usia hanya berpusat pada rentang 20-24 tahun dengan nilai media 22 tahun. Sedangkan pada penelitian sebelumnya dilaporkan median usia pada usia sekitar 30 tahun (Venkatesh, Thong, \& Xu, 2012).

\section{Kesimpulan}

Tujuan dari penelitian ini telah tercapai dengan dijabarkannya bukti-bukti empiris dari data yang telah dikumpulkan dan telah diuji. Dari hasil pengujian tersebut dapat ditarik beberapa kesimpulan. 
Pertama, berdasarkan hasil pengujian, 4 dari 6 hipotesis yang diujikan yakni $H_{1} H_{2}, H_{3}, H_{4}$ berhasil didukung sepenuhnya. Sedangkan untuk $H_{5}, H_{6}$ hanya didukung sebagian pada efek jenis kelamin dan pengalaman yang berperan sebagai moderator hubungan antara kebiasaan dengan niat perilaku dan perilaku penggunaan, sedangkan usia tidak ditemukan efek moderator yang signifikan.

Kedua, jenis kelamin terbukti secara empiris memoderati hubungan motivasi hedonis, nilai harga, kebiasaan dan kecemasan pada niat perilaku. Selain itu jenis kelamin juga memoderati hubungan kebiasaan dan kondisi-kondisi yang memfasilitasi pada perilaku penggunaan. Pria mempunyai efek yang lebih kuat pada motivasi hedonis dan kebiasaan, sedangkan wanita mempunyai efek yang lebih kuat pada nilai harga, kecemasan dan kondisi-kondisi yang memfasilitasi. Temuan ini juga menguatkan teori-teori dari penelitian sebelumnya (Venkatesh \& Morris, 2000), (Venkatesh, Morris, \& Davis, 2003), (Brown \& Venkatesh, 2005).

Ketiga, pengalaman terbukti secara empiris memoderati hubungan motivasi hedonis, kebiasaan dan kecemasan pada niat perilaku. Selain itu pengalaman juga memoderati hubungan kebiasaan dan kondisi-kondisi yang memfasilitasi pada perilaku penggunaan. Pengguna yang lebih berpengalaman memberikan efek yang lebih kuat pada kebiasaan sebaliknya pengguna yang kurang berpengalaman memberikan efek yang lebih signifikan pada motivasi hedonis, kecemasan dan kondisi-kondisi yang memfasilitasi. Temuan ini mengonfirmasi hasil penelitian-penelitian sebelumnya (Ajzen, 2002), (Kim, Malhotra, \& Narasimhan, 2005), (Van Der Heijden, 2004).

Terakhir bukti empiris yang ada juga menunjukkan bahwa usia berperan sebagai moderator dalam hubungan motivasi hedonis, kecemasan dan nilai harga terhadap niat perilaku serta hubungan kondisi-kondisi yang memfasilitasi terhadap perilaku penggunaan. Kelompok usia yang lebih muda berpengaruh signifikan terhadap motivasi hedonis, sebaliknya kelompok usia yang lebih tua mengambil peranan penting dalam kecemasan, nilai harga dan kondisi-kondisi yang memfasilitasi. Hasil penelitian ini juga telah mendukung beberapa hasil penelitian terdahulu (Lee, Cho, $\mathrm{Xu}, \&$ Fairhurst, 2010), (Limayem, Hirt, \& Cheung, 2007), (Venkatesh, Thong, \& Xu, 2012).

Berdasarkan dari hasil implikasi teoritis dan keterbatasan-keterbatasan yang ada, maka penelitian selanjutnya diarahkan untuk dapat memperbaiki dan mengembangkan lebih lanjut hasil temuan yang dilaporkan. Penelitian di masa depan dapat melakukan replikasi dan generalisasi model penelitian ini pada berbagai wilayah, kelompok populasi yang berbeda, dan teknologi yang berbeda. Metode penelitian bisa menerapkan metode lainnya seperti teknik random sampling atau metode wawancara. Selain itu dapat juga dengan memperluas model empiris pada penelitian ini dengan mengidentifikasi faktor-faktor lain yang relevan dan dapat membantu meningkatkan penerapan model teori untuk berbagai teknologi.

Beberapa konstruk yang menarik dibahas lebih lanjut untuk memperluas model empiris dalam penelitian ini antara lain konstruk ekspektasi konfirmasi (Brown, Venkatesh, \& Goyal, 2014). Beberapa variabel moderator yang dapat diteliti lebih lanjut untuk penelitian masa datang seperti status sosial, pendapatan dan tingkat pendidikan. Variabel-variabel moderator tersebut perlu diteliti lebih lanjut untuk mengetahui efeknya terhadap penerimaan teknologi informasi pada sisi konsumen. Penelitian lebih lanjut yang menarik untuk dibahas adalah terkait perilaku setelah adopsi teknologi informasi (Peng, Zhao, \& Zhu, 2014).

\section{Referensi}

Ajzen, I. (2002). Perceived Behavioral Control, Self-Efficacy, Locus of Control, and the Theory of Planned Behavior. Journal of Applied Social Psychology, 32(4), 665-683.

Ajzen, I. (2002). Residual Effects of Past on Later Behavior: Habituation and Reasoned Action Perspectives. Personality and Social Psychology Review, 6(2), 107-122.

Ajzen, I., \& Fishbein, M. (1980). Understanding attitudes and predicting social behavior (1st ed.). Englewood Cliffs: Prentice-Hall. 
Ajzen, I., \& Fishbein, M. (2005). The Influence of Attitudes on Behavior, in The Handbook of Attitudes. Erlbaum: Mahwah.

Bagozzi, R. P. (2007). The legacy of the technology acceptance model and a proposal for a paradigm shift. Journal of the Association for Information Systems, 8(4), 244-254.

Benbasat, I., \& Barki, H. (2007). Quo vadis, TAM? Journal of the Association for Information Systems, 8(4), 211-218.

Brown, S. A., Venkatesh, V., \& Goyal, S. (2014). Expectation confirmation in information systems research: A test of six competing models. MIS Quarterly, 38(3), 729-756.

Brown, S., \& Venkatesh, V. (2005). A Model of Adoption of Technology in the Household: A Baseline Model Test and Extension Incorporating Household Life Cycle. MIS Quarterly, 29(3), 205-218.

Budiarto, R. (2013). Meta-analisis TAM: Analisis pengaruh norma subjektif, kategori teknologi, status respoden dan nilai budaya terhadap penggunaan teknologi. Jak-Stik.

Chau, P. Y., \& Hui, K. L. (1998). Identifying early adopters of new IT products: A case of Windows 95. Information \& Management, 33(5), 225-230.

Davis, F. D. (1989). Perceived Usefulness, Perceived Ease of Use, and User Acceptance of Information Technology. MIS Quarterly, 13(3), 319-340.

Deaux, K., \& Lewis, L. L. (1984). Structure of gender stereotypes: Interrelationships among components and gender label. Journal of Personality and Social Psychology, 46(5), 991-1004.

El-Qadri, Z. M., \& Wijaya, T. (2013). Panduan Teknik Statistik SEM \& PLS dengan SPSS AMOS (2nd ed.). Yogyakarta: Cahaya Atma Pustaka.

Gabby, M. (2011). Tingkat efektivitas sistem informasi Remote Trading menggunakan metode UTAUT pada PT Ciptadana Securities. Jakarta: Universitas Bina Nusantara.

Garson, G. D. (2015). Structural Equation Modeling. Thousand Oaks, CA: SAGE Publications.

Group, S. (2014). The Standish Group Report Chaos. London: Project Smart. Diambil kembali dari https://www.projectsmart.co.uk/white-papers/chaos-report.pdf

Hair, J. F., Black, W. C., Babin, B. J., \& Anderson, R. E. (2010). Multivariate Data Analysis (7th ed.). New York: Peason International.

Handayani, R. (2007). Analisis faktor-faktor yang mempengaruhi minat pemanfaatan sistem informasi dan penggunaan sistem informasi (studi empiris pada perusahaan manufaktur di Bursa Efek Jakarta). Jurnal Akuntansi dan Keuangan, 9(2), 76-88.

Henning, M., \& Jardim, A. (1977). The Managerial Woman (Vol. 7). Garden City, NY: Anchor Press.

Hubona, G., \& Cheney, P. H. (2004). System Effectiveness of Knowledge-base Technology. International Conference of System Science, (hal. 532-541).

Kim, S. S., Malhotra, N. K., \& Narasimhan, S. (2005). Two Competing Perspectives on Automatic Use: A Theoretical and Empirical Comparison. Information Systems Research, 16(4), 418-432.

Lee, H.-J., Cho, H. J., Xu, W., \& Fairhurst, A. (2010). The influence of consumer traits and demographics on intention to use retail self-service checkouts. Marketing Intelligence \& Planning, 28(1), 46-58.

Lee, Y., Kozar, K. A., \& Larsen, K. R. (2003). The Technology Acceptance Model: Past, Present, and Future. Communications of the Association for Information Systems, 12(50), 752-780.

Limayem, M., Hirt, S. G., \& Cheung, C. M. (2007). How habit limits the predictive power of intention: The case of information systems continuance. MIS Quarterly, 31(4), 705-737.

Mathieson, K. (1991). Predicting User Intentions: Comparing the Technology Acceptance Model with the Theory of Planned Behavior. Information Systems Research, 2(3), 173 - 191.

Morris, M. G., Venkatesh, V., \& Ackerman, P. L. (2005). Gender and Age Differences in Employee Decisions About New Technology: An Extension to the Theory of Planned Behavior. IEEE Transactions on Engineering Management, 52(1), 69-84.

Murray, K. B., \& Häubl, G. (2007). Explaining Cognitive Lock-In: The Role of Skill-Based Habits of Use in Consumer Choice. Journal of Consumer Research, 34(1), 77-88. 
Murtadho, M. A., \& Wahid, F. (2016). Permasalahan Implementasi Sistem Informasi Di Perguruan Tinggi Swasta. Register: Jurnal Ilmiah Teknologi Sistem Informasi, 2(1), 17-21.

Murugesh-Warren, A., Sudbury, D., Saeed, A., Nnajiuba, U., Mashayekhi, S., Abdel-Gadir, S., . . Cox, B. (2015). An extension of the UTAUT 2 with a focus of age in healt What do different ages want? International Journal of Integrated Care, 15, 1-3.

Mustakini, J. H. (2008). Metode Penelitian Sistem Informasi (1st ed.). Yogyakarta: Andi.

Notani, A. S. (1998). Moderators of Perceived Behavioral Control's Predictiveness in the Theory of Planned Behavior: A Meta-Analysis. Journal of Consumer Psychology, 7(3), 247-271.

Peng, X., Zhao, Y., \& Zhu, Q. (2014). Understanding post adoption switching behavior for mobile instant messaging application in China: Based on migration theory. PACIS (hal. 1-11). Chengdu, China: Association for Information Systems.

Pressman, R. S., \& Maxim, B. R. (2014). Software Engineering: A Practitioner's Approach (8th ed.). New York: McGraw-Hill Higher Education.

Ramdhani, A. (2009). Analisis adopsi teknologi komputer dengan pendekatan structural equation modeling: studi empiris pada asisten dosen Universitas Indonesia. Jakarta: Fakultas Ilmu Komputer Universitas Indonesia.

Sam, H. K., Othman, A. E., \& Nordin, Z. S. (2005). Computer Self-Efficacy, Computer Anxiety, and Attitudes toward the Internet: A Study among Undergraduates in Unimas. Journal of Educational Technology \& Society, 8(4), 205-219.

Sedana, I. G., \& Wijaya, S. W. (2010). UTAUT Model for Understanding Learning Management System. Internetworking Indpnesia Journal, 2(2), 27-32.

Slama, M. E., \& Tashchian, A. (1985). Selected Socioeconomic and Demographic Characteristics Associated with Purchasing Involvement. Journal of Marketing, 49(1), 72-82.

Van Der Heijden, H. (2004). User Acceptance of Hedonic Information Systems. MIS Quarterly, 28(4), 695-704.

Venkatesh, V., \& Bala, H. (2008). Technology Acceptance Model 3 and a Research Agenda on Interventions. Decision Sciences, 39(2), 273-315.

Venkatesh, V., \& Morris, M. (2000). Why Don't Men Ever Stop to Ask for Directions? Gender, Social Influence, and Their Role in Technology Acceptance and Usage Behavior. MIS Quarterly, 115-139.

Venkatesh, V., Davis, F. D., \& Morris, M. G. (2007). Dead Or Alive? The Development, Trajectory And Future Of Technology Adoption Research. Journal of the Association for Information Systems, 8(4), 267286.

Venkatesh, V., Morris, \& Davis. (2003). User Acceptance of Information Technology: Toward a Unified View. MIS Quarterly, 3(27), 425-478.

Venkatesh, V., Thong, J. Y., \& Xu, X. (2012). Consumer Acceptance and Use of Information Technology: Extending the Unified Theory of Acceptance and Use of Technology. MIS Quarterly, 36(1), 157-178.

Widhiarso, W. (2012, Juni 18). Reliabilitas dan Validitas Konstruk dalam Pemodelan Persamaan Struktural (SEM). Yogyakarta, Yogyakarta, Indonesia: Fakultas Psikologi Universitas Gadjah Mada. Diambil kembali dari http://wahyupsy.blog.ugm.ac.id/2012/06/18/reliabilitas-dan-validitaskonstruk-dalam-pemodelan-persamaan-struktural-sem/

Widiatmika, I. M., \& Sensuse, D. I. (2008). Pengembangan model penerimaan teknologi internet oleh pelajar dengan menggunakan konsep Technology Acceptance Model (TAM). Jurnal Sistem Informasi, 4(2), 81-92. 